\title{
Shigellosis: Its Prevention and Management Issues
}

\author{
Prabhurajeshwar $\mathbf{C}^{1}$ and Kelmani Chandrakanth $\mathbf{R}^{2 *}$ \\ Department of Microbiology, Gulbarga Institute of Medical Sciences, India \\ Department of Post Graduate Studies and Research in Biotechnology, Gulbarga University, India
}

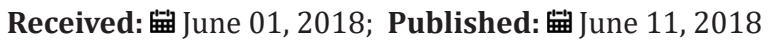

*Corresponding author: Chandrakanth Kelmani R, Medical Biotechnology and Phage Therapy Laboratory, Department of Post Graduate Studies and Research in Biotechnology, Gulbarga University, Gulbarga-585 106, Karnataka, India

\section{Abstract}

Objective: This paper has reviewed researches that acquired from peer-looked into literary works on Shigellosis. Food borne diseases identified with unhygienic nourishment taking care of practices remain a noteworthy general medical issue over the globe. The issue is thorough in creating nations because of limitations in securing most possible hygienic food handling practices.

Study Outline: Information shows that an expected $75 \%$ of instances of diarrheal diseases are connected with the spending of food contaminated with pathogenic microorganisms. Bacillary dysentery (Shigellosis) is a serious human illness caused by Shigellae.

Methods: It is one of the significant wellsprings of dysentery in creating nations. The exact assessments of grimness and mortality because of shigellosis are deficient; anyway it is far reaching and has been accounted for to cause numerous flare-ups. The restricted data accessible indicates Shigella to be an essential sustenance borne pathogen in creating nations.

Results: In this Survey, it is prestigious that pathogenic Shigella is as yet general medical issue. Thusly, a lot of data has been produced concerning the host, pathogen and natural factors that affect the pathogenesis of shigellosis at the cell and sub-atomic level and condenses what is at present thought about Shigella, elementing those highlights that add to pathogenesis and researching the current advance in the improvement of protected and minimal effort multivalent immunization.

Conclusion: Accordingly this survey is engaged upon the study of disease transmission, sickness load and the helpful difficulties of Shigellosis in creating nations recognition.

Keywords: Shigellosis; Epidemiology; MDR; Pathogenesis; Shigella; Food-Borne Pathogens; Antibiotic Resistance; Diarrhoea; A Flow Through

\section{Introduction}

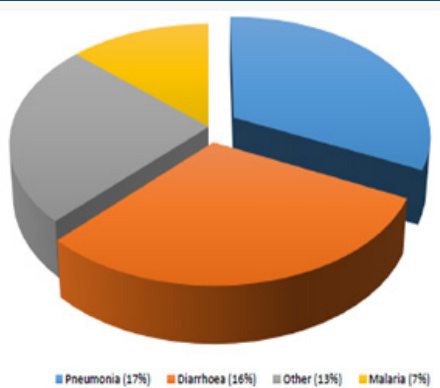

Figure 1: Proportional distribution of cause of disease among children below five years of age in India (Source: Based on WHO, Global Burden of Diseases estimates to the most recent estimates for the total number of less thanfive deaths).
In medicine, "' signifies "a flow through", likewise characterized as "the entry of at least three free or fluid stools every day, more much of the time than is typical for the identity" [1,2]. On the off chance that left untreated, diarrhoea can prompt extreme drying out, which can bring about hospitalization or even demise. Dysentery disease is broad everywhere throughout the world, debilitates human wellbeing as well as incredibly impact society and worldwide economy. The casualty rate by dysentery disease exceedingly positions fourth among every one of the diseases, just lower than tumor, Cardiovascular or Cerebral vessels sicknesses and diabetes mellitus, impacts are more awful in creating nations and low income nations and it has wound up one of issues of the overall real general wellbeing. WHO treats the sort out of diarrhoea 
infection as worldwide technique and furthermore as per the plan of control of dysentery ailment was sanctioned in May, 1978 (Figure 1).

It is usually the symptom of gastrointestinal infection, most cases of diarrhoea in children result from infection caused by a genus of viruses, bacteria or parasites, which disturb the normal fluid and nutrient assimilation of the intestines. According to UNICEF information: Observing the circumstance of Kids and Ladies report June 2016, diarrheal diseases representing 9\% of all deaths among the kids under-five years old making them the second to a great extent basic reason for youngster deaths around the world. This converts into more than 1,400 youthful youngsters biting the dust every day or about 1.34 million deaths per year [3] most deaths from dysentery happen alongside kids under 2 years old living in South Asia and sub-Saharan Africa. Over portion of the casualty happens in only five nations: India, Nigeria, Afghanistan, Pakistan and Ethiopia.

As it center, in creating nations like India, diarrheal contamination remains a noteworthy medical issue, because of contamination constitute a noteworthy weight illness [4]. Fifteen nations contribute three divisions of youth causality because of dysentery in kids under five years old worldwide out of which India positions initial [5]. In India intense diarrheal diseases prompt $13 \%$ deaths under five years old gathering, for the time of 2009 , concerning 11.2 million cases with 1,762 deaths were accounted [6]. As indicated by a factual study, by National Foundation of Cholera and Enteric Infection, Kolkata, (India), essential passing rate because of dysentery in country India is 9.3 for each 1,000 populaces and the diarrheal deaths represent $22 \%$ of aggregate provincial deaths among 0 to six years age bunch youngsters (NICED, Kolkata). Rotavirus is the absolute most basic pathogen which causes gastroenteritis in together created and creating nations however the slant of bacterial enteropathogens change generally amongst created and creating nations [7].

The reasons for relentless diarrhoea in populaces are ineffectively comprehended. Five sorts of Escherichia coli are in charge of fundamentally $25 \%$ of every diarrheal sickness in creating nations. Shigella species are responsible for 10 to $15 \%$ of extreme diarrheas in youngsters under 5 years old. Other bacterial enteropathogens are Vibrio cholera, Campylobacter jejuni, Aeromonas species, Bacteroides fragilis and Providencia alkalifaciens gave off an impression of being the most widely recognized etiological causes yet certain circumstances are related through and especially high frequency of intense diarrheal diseases [8]. The patterns of bacterial enter pathogens causing gastroenteritis continue adjusting with change in example of living and natural cleanliness [7]. So the occasional restoration of the learning concerning the patterns of the bacterial enter pathogens is exceptionally significant. An epidemiologic amendment of an infectious disease in a group is always estimated to be an essential activity towards the presentation of the best possible inclusions for overprotective of ailment since the Characteristics and the model of seclusion of etiologic specialists of the infection vacillate from place to put contingent upon the limited meteorology, geology and financial components [9].

\section{An Introduction to Shigella Bacteria}

Shigella is types of enterobacteria that begin diseases in people and different primates $[10,11]$. The disease started by the ingestion of Shigella bacteria is eluded as Shigellosis. Shigellosis is a bacterial disease of the intestinal tract caused through microbes of the sort Shigella and showed by diarrhoea. This is a notable specialist of bacillary dysentery, infantile diarrhoea everywhere throughout the world and more genuine than the normal "stomach influenza". Shigella species was the second most boundless bacterial specialists causing dysentery after Escherichia coli (E. coli) [12]. Shigellosis is endemic to numerous creating nations and furthermore happens in episode causing considerable bleakness and mortality. The preeminent manifestation of this contamination is wicked diarrhoea and the slightest infective dosage is as low as 10-100 bacterial cells because of virtual protection from stomach corrosive. Shigellosis is a noteworthy general wellbeing concern around the world, for the most part in creating nations $[13,14]$. Shigella disease is portrayed with high fever ( $\left.>38.5^{\circ} \mathrm{C}\left[101.3^{\circ} \mathrm{F}\right]\right)$, stomach spasms, dysentery, tenesmus, and polymorph atomic leukocytes on a methylene blue stain of the fecal issue; extra intestinal appearances and entanglements additionally happen.

\section{Evaluation and Identification of Shigella}

The various kinds of Shigella bacteria have been named after the lead laborers who found every one 10, [11,15]. The primary bacterium to be found, Shigella dysentriae, was named after Kiyoshi Shiga, a Japanese researcher who found it in 1896 as exploring a vast pestilence of diarrhea in Japan [16,17]. The bacterium was additionally alluded to a sort of for the most part as the dysentery (bacillus alluding to a class of Gram-positive, pole molded microorganisms of which Shigella is a part) [17]. In synopsis distributed every year, the CDC gives an outline of the arrangement of different sorts (species) of Shigella microbes as; the class Shigella comprises of four noteworthy serological gatherings having a place A with D as indicated by their 0-polysaccharide antigens subsequenting to the four species, correspondingly [18]. In current scientific categorization, these four serological subgroups are acknowledged as four species inside the class Shigella: Shigella dysentriae (S. dysentriae), Shigella flexneri (S. flexneri), Shigella boydii (S. boydii) and Shigella sonnei (S. sonnei). The four unmistakable species can be recognized based on serogrouping and biochemical examination [19]. Around $70 \%$ of the kids with Shigellosis are contaminated with Shigella flexneri, 20\% with Shigella sonnei and the staying $10 \%$ with Shigella dysentriae or Shigella boydii. 


\section{General Characteristics and The study of disease transmission of Genus Shigella}

The cells of the Shigella species are Gram-negative bacilli, nonmotile, non-spore-shaping, facultative anaerobic bars [20]. Shigella is separated from the firmly related Escherichia coli based on pathogenicity, physiology (inability to age lactose or decarboxylation lysine) and serology. They are by and large catalase positive and oxidase and lactose negative. They mature sugars, as a rule without framing gas. The strains can at temperatures going from $200 \mathrm{C}$ and $460 \mathrm{C}$, with an ideal at $370 \mathrm{C}$ and at a pH scope of 5.0 to 7.5. The basic specific or differential agar media utilized for the refined of Shigella are MacConkey (Macintosh), Xylose Lysine Deoxycholate (XLD), Hektoen (HEK), Salmonella-Shigella (SS), Deoxycholate Citrate Agar (DCA). The sort is isolated into four serogroups with more than 2,500 recognized numerous serotypes $[21,22]$.

The genus Shigella was partitioned into four species viz., Shigella dysentriae (serogroup A), Shigella flexneri (serogroup B), Shigella boydii (serogroup C) and Shigella sonnei (serogroup D). In view of the varieties in their 0-polysaccharide part of their LPS, the species were additionally characterized into a few serotypes, as $S$. dysentriae known to have 15 serotypes, $S$. flexneri have 14 serotypes and sub serotypes, S. boydii 20 serotypes and S. sonnei with a solitary serotype $[23,24]$ (Table 1 ). Shigellosis is a worldwide human medical issue. Yearly, there are 165 million instances of shigellosis bringing about 1.1 million passings in the creating scene with high bleakness and mortality $(99 \%)[25,26]$. Of these 1.1 million passings because of Shigella, 69\% are in youngsters matured under five years [23,25]. It is endemic in most creating nations where substandard cleanliness and perilous water supplies, in thickly populated regions and establishments [27,28]. People are the main regular hosts for Shigella. Both endemic and pandemic shigellosis is available in creating nations. Among 69\% diseases, $61 \%$ of all passings were accounted for in the kids under 5 years old. S. flexneri and S. sonnei were in charge of expanded level of diseases in the creating and also in the industrialized nations. It has been accounted for that every year around 58 million voyagers from industrialized nations were influenced. Bacillary dysentery was likewise revealed among the military troops [23].

Table 1: Species and Serogroups of Shigella Thomas and Gerald [21], Kotloff [23].

\begin{tabular}{|c|c|c|c|}
\hline Species & Serogroup & Serotypes & \\
\hline S. dysentriae & A & $1-12$ & $\begin{array}{c}\text { Most common, } \\
\text { with outbreaks }\end{array}$ \\
\hline S. flexneri & B & $\begin{array}{c}1-6 \\
\text { (with 15 subtypes) }\end{array}$ & $\begin{array}{c}\text { Developing } \\
\text { Countries }\end{array}$ \\
\hline S. boydii & C & $1-18$ & \\
\hline S. sonnei & D & 1 & $\begin{array}{c}\text { Developed } \\
\text { countries* }\end{array}$ \\
\hline
\end{tabular}

Amid a sporadic flare-up of diarrhoea in Kolkata, S. dysentriae type I and S. flexneri were the commonest serotypes found in the tried feces tests of the patients [29-32]. An observation report of Shigella diseases in Indonesia expresses that Shigella was disengaged from $9.3 \%$ of diarrhoea patients in the wellbeing focuses. S. flexneri was found in $5.9 \%$ of patients, and was the most incessant species disengaged, involving 63.2\% (36/57) of all Shigella species confined. Shigella species were discovered altogether more frequently among youngsters more than 2 years of age, and the rate of confinement expanded with age. In a multicentre investigation of Shigella contamination in six Asian nations, S. flexneri was observed to be transcendent in Bangladesh, China, Pakistan, Indonesia and Vietnam site while $S$. sonnei was regular in Thailand; S. boydii was in charge of the arrangement of disease in Bangladesh. Kimura et al. [33], revealed about $S$. sonnei flare-up in Joined States through the monetarily arranged sustenance. S. boydii [34] was for the most part discovered just in the Indian subcontinent [25]. Stool with bodily fluid as well as blood were the fundamental attributes of Shigella disease in these patients [35]. Meta-investigation from PubMed and Chinese biomedical writing database demonstrated the prevalence of $S$. flexneri and $S$. sonnei in territory China from 2001 until 2012 [36].

The most much of the time announced factor related with the inclusion of the tainted specialist was exposed hand contact with the sustenance took after by inability to legitimately wash hands, lacking cleaning of handling or planning hardware or utensils, cross-sullying of prepared to-eat food by debased crude fixings. In Joined States and Europe, youngsters in day-mind focuses, transient specialists, voyagers to creating nations and people in custodial foundations are tainted regularly [37].

\section{Science and Natural chemistry of Shigella species}

Upon ingestion, the microbes keep on existing in the gastric condition of the stomach or guts and advance toward the internal organ. Where it appends and enters the epithelial cells of the intestinal mucosa. Post intrusion, Shigella increases intracellular and spreads to Neighboring epithelial cells bringing about tissue obliteration and agent pathology of shigellosis. For the most part, Shigella clings to the film of the cell and is disguised by an endosome which it thusly lyses to access the cytoplasm where duplication happens [38]. Shigella contaminates the host amid the M-cells in the gut epithelia of the small digestive system, as they can't enter specifically through the epithelial cells. Utilizing a Sort III emission framework going about as a natural syringe, the bacterium infuses Intrusion plasmid antigen $\mathrm{D}$ (IpaD) proteins into cells, activating bacterial taint and the ensuing lyses of vacuolar layers utilizing IpaB and IpaC proteins [23]. Extracellular Shigella isn't motile yet intracellularly it can move involving the whole cytoplasm of the tainted cell and between cells. It utilizes a system for its motility by which its Ics A and IcsB proteins trigger activity polymerization in the host cell (by means of N-WASP enrollment of Arp2/3 edifices) in a rocket impetus mold for cell-to cell spread [39]. In particular, 
evaluation between adjoining cells is encouraged by the IcsA protein.

After fruitful epithelial cell attack and entrance of the colonic mucosa by the microbes, there is weakening of the epithelium and irritation of the lamina propria coming full circle in desquamation and ulceration of the mucosa and ensuing spillage of blood, provocative components and bodily fluid into the intestinal lumen [23]. In this manner the trademark section of repetitive and measly dysenteric stool blended with blood and bodily fluid. Retention of water by the colon is restrained under these conditions [20]. A few strains of Shigella deliver enterotoxins and shiga-poisons like the verotoxins of E. coli 0157:H7. The poison has a sub-atomic weight of $68 \mathrm{kDa}$ and is a multi-subunit protein comprising of one particle of an A subunit $(32,000 \mathrm{MW})$ and five atoms of the B subunit $(7,700 \mathrm{MW})$. Both shiga-poisons and verotoxins are related with haemolytic uremic disorder (HUS), Haemolytic colitis and diarrhea 39. The names of these conditions are reliant on the causative life form and Symptoms extend from serious dysentery, stomach agony, heaving and ridiculous pee. Every one of the Shigella genomes incorporates a destructiveness plasmid that encodes moderated essential harmfulness determinants. The Shigella chromosomes share the greater part of their Characteristics with those of E. coli K12 strain MG1655 20. No cure exists for these poisons. In this way steady care requires upkeep of liquid and electrolyte levels and observing and bolster for kidney work. Inactivation of the poison is accomplished by steam treatment, oxidizing operators, for example, blanch and synthetic sanitizing specialists, for example, glutaraldehyde. The poison follows up on the coating of the veins, the vascular endothelium. The B subunits of the poison tie to a cell film segment, Gb3, and the unpredictable enters the cell. Once inside, the A subunit collaborates with the ribosomes to inactivate them. The A subunit of the Shiga-poison is a Glycosidase that adjusts the RNA part of the ribosome to inactivate it and along these lines convey a stop to protein amalgamation of the cell prompting cell demise [40].

The vascular endothelium needs to consistently reestablish itself. Thus, cell demise prompts breakdown of the covering prompting discharge. The essential reaction is naturally ridiculous dysentery. For unexplained reasons, the poison is apparently powerful against little veins, for example, found in the stomach related tract, kidneys and lungs however not against vessels, for example, the supply routes or real veins. A particular focus for the poison has all the earmarks of being the vascular endothelium of the glomerulus devastating the structures and finishing up in kidney disappointment and the improvement of the regularly destructive and visit weakening haemolytic uremic disorder. Sustenance harming with Shiga-poison frequently affects the lungs and the sensory system [41].

\section{Clinical Sign}

Shigella spp. is the causative operator of the ailment shigellosis. This extreme intestinal contamination is likewise called as bacillary diarrhea. All inclusive, this disease is known as a noteworthy weight in general social insurance [23]. It is as a matter of first importance an infection of people. The disease is described by harm of the colonic epithelium took after by intracellular and intercellular spread, disease in the close-by or close to cells and the host's intense fiery responses prompts colitis of the mucosa. It brings about the spillage of blood and mucous in the intestinal lumen [41]. Since the illness is obtained through the fecal-oral course, the thoroughness and the arrangement of Symptoms might be reliant upon the quantity of life forms ingested. The Symptoms fluctuate from mellow watery diarrhoea to serious fiery diarrhea with the entry of regular bleeding and mucoid stools. Alternate Symptoms incorporate fever, disquietude, stomach cramping and shakings. The start of manifestations normally happens inside 24 to 48 hours of ingestion of the etiologic specialist. Like different difficulties of shigellosis incorporate bacteraemia, septicaemia, hypoglycaemia, drying out, haemolytic-uremic disorder, responsive joint inflammation, dangerous megacolon and other neurological issues [42]. The people tainted with $S$. flexneri in this way create torment in their joints, bothering of the eyes and agonizing pee. This condition is called Reiter's disorder. It is the late inconvenience of $S$. flexneri disease and goes on for quite a long time which prompts unending joint pain. Shiga poison of S. dysentriae type I is in charge of the Haemolytic-uremic disorder. Normally, shigellosis is a self-restricting ailment. Perilous are frequently observed in malnourished newborn children and youthful youngsters under 5 years old, likewise in elderly individuals who have frail safe framework $[23,43,44]$.

\section{Pathogenesis of Shigella}

Disease is started by ingestion of Shigellae (for the most part by means of fecal-oral sullying). The creature enters the host and goes through the stomach related framework until the point that it achieves the internal organ. All in all the disease is constrained to the intestinal mucosa. Pathogenesis is started by the attack through the basal face of the intestinal epithelium by Shigella. In this way, after achieving the digestive organ, Shigella is taken up in vacuoles by microfold cell (M cells) which are particular structure of the follicle related epithelium which covers the mucosal lymphoid follicles, the empowering site of the mucosal safe framework $[45,46]$. The living being escapes from the vacuole lastly goes to basic macrophages that are related with $\mathrm{M}$ cell-related lymphoid follicles [47]. Shigella is phagocytised by macrophages in the arch zone of these follicles, which at that point actuates apoptosis which brings about the escape of the pathogen to the basal side of the colonic epithelium. Concentrates additionally report that harmful $S$. flexneri makes obliteration the host cell mitochondria and triggers corruption in the contaminated human monocyte determined macrophage [48]. Another investigation showed that Shigella incited mitochondrial brokenness in non myeloid cells; result in caspase-autonomous necrotic cell passing through another pathway amid oxidative cell worry in epithelial cells [49]. Passing of the macrophage brings about the arrival of proinflammatory cytokine IL-12 which in the 
end brings about the enlistment of polymorphonuclear (PMN) cells to the site of disease and the beginning of aggravation $[47,50,51]$.

Then, the microbes incite their own take-up into colonic epithelial cells and spread along the side through the cells of the epithelium by a procedure known as activity based motility (ABM) through the comet tail evaluation [52]. This actin based filamentous tail moves the Shigellae into the projections on the touching enterocytes. Amid cell-cell spread the plasma layer conceals the microbes are lysed which brings about the intracellular replication and intercellular bacterial spread [47,53]. As the irritation holds on and extends, the invasion of the PMNs encourages the section of extra microbes onto the epithelium. Eventually, it is the cells of the host's resistant framework that reason irritation and ulceration of the mucosa to the colon and builds up the indications related with shigellosis [45,54-57]. It has been accounted for that the annihilation of epithelial cells in the test models of shigellosis is because of the host provocative reaction and likely not by the intracellular duplication of the pathogen [58].

\section{Transmission of and Disease with Shigella}

Shigella diseases are extremely transmissible; transmission of the ailment is for the most part by individual to-individual contact through debased hands [59]. Episodes in kids reliably happen under circumstance partner close physical contact, for example, those go over in day-mind focuses, nursing homes, custodial foundations, voyage ships, native reservations and pressed displaced person camps, with low cleanliness rehearses and debased sustenance or water filling in as the vehicle for disease [60-63]. It is approximated that up $80 \%$ of all disease is the consequence of shigellosis transmission; the infectious dosage is as low as 10-100 life form. Various investigations have uncovered an expanded recurrence of shigellosis cases in youthful grown-up men dwelling in urban settings who have pretty much nothing, assuming any; revelation to these customarily perceived hazard gatherings. Albeit a portion of these investigations assigned that sex between men ready to be a hazard factor, the majority of these examinations unfolded before the HIV plague [64].

Shigella diseases likewise might be procured from utilization of tainted nourishment. In the created and creating nations, occurrence of food borne disease is referred to through food Net, a revealing framework utilized by general wellbeing organizations that involves food borne ailment in more than $13 \%$ of the number of inhabitants in the ten pathogens; Salmonella, Campylobacter and Shigella are in charge of most instances of foodborne ailment. An expected $20 \%$ of the aggregate number of instances of shigellosis included nourishment as the vehicle of transmission [64].

\section{Symptoms of Shigella disease}

Shigellosis has gentle disease cause low grade fever (around 100.4 to $1020 \mathrm{~F}$ [ 38 to $38.9 \mathrm{0C}$ ]) and watery the runs, fever, stomach spasms and stomach torment one to four days after individuals presented to the microorganisms, Symptoms may begin 6-72 hours after infusion. A few grown-ups not have a fever. In grown-ups, the principal signs might be difficult stomach issues and a constant aching to discharge. Passing stool may incidentally alleviate the agony. These Symptoms may form into more extreme and seem all the for the most part as the contamination advances. Genuine diseases may cause low grade or direct fever and watery dysentery that advance to diarrhea. Shigella microbes deliver poisons that would invasion be able to the coating of the internal organ, prompt swelling, ulcers on the intestinal divider and wicked dysentery. The seriousness of the dysentery separates Shigellosis from routine the runs. In kids with Shigellosis, the essential defecation is regularly outsized and watery. Later solid discharges might be littler, visit, however stool may have blood, discharge and bodily fluid in it.

In exceptionally extreme instances of Shigellosis, a contaminated individual may have seizures, an inflexible neck, a cerebral pain, intense tiredness and vulnerability. Shigellosis can likewise prompt lack of hydration and in odd cases, different inconveniences, similar to joint pain, skin rashes and kidney disappointment. Maybe a few cases in kids with genuine instances of Shigellosis ought to be hospitalized. Shigellosis more often than not settles in 5 to 7 days [65]. An extreme contamination with high fever might have with seizures in youngsters less than two years of age 28. A few people who are contaminated may have no signs by any stretch of the imagination, however may in any case overwhelm the Shigella microbes to others $[10,15]$.

\section{Prevalence of Shigella disease}

Most Shigella diseases result sporadically, yet tremendous Shigella plague have been followed to defiled nourishment and water. The CDC evaluates that 4,50,000 aggregate of Shigellosis show up in the advancement nations consistently $[15,66]$. In neighborhood Gulbarga area and encompassing locale of Gulbarga (Karnataka state), dysentery has been evaluated to be in charge of roughly $11-13 \%$ of all youth disease, with a populace of around $5,32,031$. Among the four types of Shigella, Shigella dysentriae and Shigella flexnerii were more overwhelming one [67]. Shigellosis likewise portrayed via regularity with the biggest level of accounted cases happening amongst July and October and the littlest rate happening in January, February and Walk 28. Non-flare-up diseases represent the greater part of cases and when all is said in done, the exact means through which people are tainted (hazard factors) are not yet all around prestigious or comprehended. Shigella is an especially regular reason of sickness among youthful kids, in vast part since it is hard to control the spread of the bacteria in daymind settings [10]. The manifestations of shigellosis fluctuate so generally that kids shedding Shigella in their stool may demonstrate no signs of contamination. A man contaminated with Shigella can be asymptomatic (demonstrate no Symptoms of disease), experience the ill effects of direct to thorough dysentery, or endure intricacies up to and including demise [15]. 


\section{Antimicrobial Resistance in Shigella microorganisms}

Antimicrobial Resistance in pathogenic microorganisms is creating and expanding danger to human wellbeing $[68,69]$. Doctors are logically mindful that antimicrobial opposition is expanding in bacterial pathogens and that, thus, patients who are prescribed anti-infection agents are at expanded hazard for advancing antimicrobial-safe different contaminations [70]. Absolutely, "expanded recurrence of treatment disappointments for intense sickness and expanded tireless of contamination might be connoted by proceeded with length of ailment, expanded recurrence of circulatory system diseases, expanded hospitalization or extended casualty". The need of antimicrobial operators in the encourage of nourishment creatures is assessed by the FDA to be more than 100 million pounds for every year. It is assessed that $36 \%$ to $70 \%$ of all anti-toxins delivered in the Assembled States are utilized as a part of sustenance creature nourish or in safeguard treatment to counter creature ailment [68]. In 2002, the Minnesota Therapeutic Affiliation printed an article by David Wallinga, M.D., M.P.H. who composed: As indicated by the [Union of Concerned Scientists] percent of whole antimicrobials utilized as a part of the Assembled States and creating nations for all expectations or around 24.6 million pounds yearly are encouraged to poultry, swine and meat cows for no therapeutic point, in the non appearance of sickness. Over half are "restoratively critical" antimicrobials; indistinguishable or so firmly identified with human solutions that protection from the creature pharmaceutical can give protection from the comparable human medication. Penicillin, antibiotic medication, macrolides, streptogramins and sulphonamides are unmistakable illustrations [71] (Figure 2).

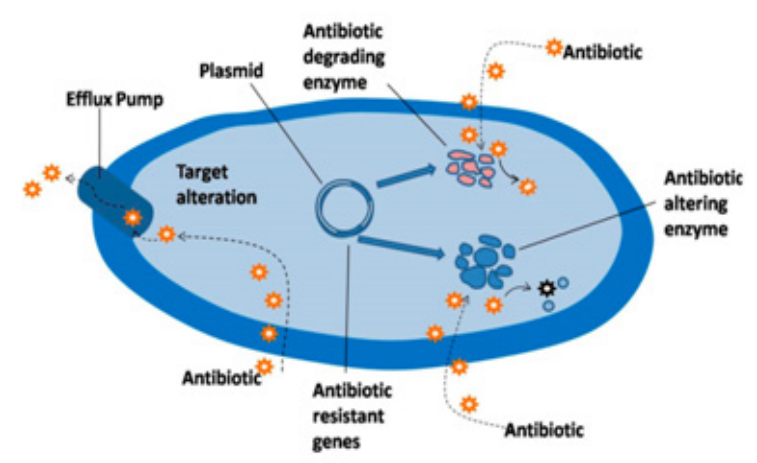

Figure 2: Chief Bacterial targets and various ways of resisting the action of antibiotics.

Vital enteric pathogens like Vibrio cholera, E.coli, Shigella spp, Salmonella spp and Campylobacter jejuni are ending up continuously more impervious to the real anti-infection agents that are required for ideal treatment of patients and these bacterial pathogens are exceptionally different from each other. They cause very extraordinary clinical disorders; their biology, the study of disease transmission and strategy for transmission are particular and they are normally isolated hereditarily. The way that such extraordinary life forms are growing progressively anti-toxin safe underlines the inescapability of the weights that prompt the rise and spread of Resistance. Over the previous decades, Shigella species demonstrate an example of relentlessly expanding and have turned out to be significantly more impervious to most broadly utilized antimicrobials [72,73]. The expanding levels of antimicrobial opposition of Shigella confines have entangled the treatment of shigellosis. The antimicrobial opposition form of Shigella species vary as per geographic territory and in a similar place after some time, prompting helpful issues [74-77]. Intermittent local checking of infection with serotype breakdown and normal occasional anti-toxin helplessness testing method of detaches to direct neighborhood experimental treatment are imperative variables for the satisfactory control of shigellosis [78].

The clinical results of anti-toxin opposition contrast among the pathogenic bacteria the runs operators. For shigellosis, antiinfection agents are the essential treatment. Patients treated with an incapable anti-toxin may have a bigger number of difficulties than condition that; they had not been dealt with, since the antimicrobial is probably going to influence the ordinary intestinal vegetation, subsequently really supporting the evaluation of the safe Shigella.

Infantile diarrhoea is a noteworthy infection and has been representing an immense shared medical issue in creating nations like India throughout the years. The conventional antishigellosis drugs chlormaphenicol, ampicillin and sulphamethoxazole have formed into obsolete. As of late, fluoroquinolones, particularly ciprofloxacin have been exceptionally effective in fighting Shigellosis yet sadly, safe strains have risen. The rise of abnormal state ciprofloxacin Resistance in Shigella sps has additionally been accounted for in India [79] among Shigella represents a noteworthy remedial test to deal with this sickness. One reason for rise of multimedicate safe Shigella sps is the special capacity of the pathogen to secure Resistance factors (transmissible Characteristics) from nature or from other bacteria. Antimicrobial Resistance is generally given by specific Characteristics. Countless related Characteristics have detailed for each gathering of antimicrobials. It is difficult to contemplate all the announced Characteristics, so most regularly disengaged dominating disconnects and revealed Characteristics were chosen for this investigation. Fluoroquinolone, particularly ciprofloxacin are the most consistently utilized medications for Shigellosis treatment. Lessened helplessness to the fluoroquinolone gathering of anti-infection agents is typically connected with point transformations in the bacterial target Characteristics gyrA, gyrB encoding DNA gyrase and parC, parE encoding DNA topoisomerase IV.

At show, multi-sedate opposition has entangled the groupings of exact specialists utilized for treatment of Shigellosis, especially in kids. The rise of fluoroquinolone opposition in Shigella sps and their spread over the nation's [80] due to: 
i) Point transformations, natural Resistance and additional chromosomal opposition that outcome in amino corrosive substitution in chromosomal Characteristics planned for DNA gyrase and topoisomerase IV, the objectives of fluoroquinolone activity [81].

ii) Changes in articulation of efflux pumps and external layer piousness to encourage control the amassing of these operators inside the bacterial cells [82].

iii) A extensive genus of sub-atomic component, for example, the nearness of $\beta$-lactamases dihydrofolate reductase, Chl acetyltransferase (Feline) catalysts and numerous others [8385].

These gained instruments of survival by Shigella sps have added to the industriousness of this pathogen, subsequently making the anti-toxin treatment disappointment. Setting up the aversion and treatment conventions with normal examples in such manner is by all accounts vital.

\section{Prevention and Control}

The most valuable techniques for controlling shigellosis are essential of protected and copious water and proficient defecation transfer. Anticipation of dysentery caused by Shigella depends for the most part on measures that counteract spread of the life form inside the group and from individual to individual 26. These include:

i) Hand-washing with cleanser.

ii) Ensuring the accessibility of safe drinking water.

iii) Safely discarding human waste.

iv) Breastfeeding of newborn children and youthful youngsters.

v) Safe dealing with and preparing of nourishment.

vi) Control of flies.

These measures won't just diminish the event of shigellosis, yet of other diarrhoeal diseases also. In all cases, wellbeing instruction and the collaboration of the group in executing control measures are essential. When all is said in done, a few investigations and Edwards [86] revealed that the best mediation way to deal with limit dreariness and mortality would include thorough media and individual effort programs comprising of the accompanying segments:

i) Education of all inhabitants to effectively evade fecal sullying of sustenance and water and to energize.

ii) Hand washing after crap.

iii) Encourage mother to bosom bolster babies.

iv) Promote the utilization of oral rehydration treatment to balance the impacts of intense dysentery. v) Encourage moms to give recovering nourishing consideration as additional sustenance for youngsters.

vi) Recovering from diarrhoea or dysentery.

The contribution to keep away from disease by Shigella is aversion of fecal sullying in drinking water and nourishment supplies. Since the main wellspring of this operator is tainted people, it is conceivable to control transmission by appropriate cleanliness, squander administration, water sanitization and treatment of the debilitated. Wellbeing instruction is crucial to hoist open mindfulness and incite conduct change. Inoculation: There is a solid requirement for a compelling, protected and minimal effort antibody against shigellosis [44]. The high disease weight of shigellosis in creating nations, kids $<5 \mathrm{yr}$ of age as the center sufferers, trouble in achieving satisfactory sanitation and individual cleanliness in these districts and rare restorative choices for rising various medication resistnace Shigella point towards inoculation as a desire for successful and feasible approach against shigellosis. Shigellosis is focused by WHO as one of those enteric diseases for which novel antibodies are most required, the objective populaces being explorers from created nations and military administration work force, and also youngsters existing in endemic territories $[23,44]$.

Despite the fact that the requirement for a Shigella antibody is dire, very little improvement has been done because of the antigenic many-sided grade, absence of between species cross-defensive epitopes and holes in comprehension of the defensive safe reaction. Various assorted kinds of immunizations against Shigella have been tentatively tried in creature models and in volunteer trials [87]. Different live constricted antibodies, for example, the old parenteral slaughtered entire cell immunization was viable however delivered solid reactions in light of LPS. Yang et al., [88] demonstrated that two protected and valuable antibodies are currently authorized and accessible. One depends on characterized subunit antigens (Vi polysaccharide, is given in a solitary dosage Subcutaneous), the other on entire cell live constricted microbes (the live oral immunization Ty2la, accessible in enteric-covered case or fluid definition [89]. Inoculation against shigellosis previously or amid an episode condition ought to thusly be basically considered as a powerful instrument.

\section{Conclusion}

Shigellosis remains an essential general medical issue and delivers a significant worldwide disease burden, especially for youthful youngsters in creating nations being of epidemiological significance. Flare-ups of contamination with Shigella species are hard to control as a result of the low infectious inoculum and ease of transmission. Antimicrobial treatment is pushed for shigellosis to abbreviate the span of sickness. Be that as it may, in creating nations like India, antimicrobial opposition is a rising issue in Shigella species, treatment alternatives are getting to be constrained all around and bringing about diminished efficacies of 
antimicrobial treatment. Fast rise of protection from antimicrobials after some time warrants the requirement for ceaseless observing of affectability examples and this has turned into a test in the administration of shigellosis. So the practicing the prevention, management issue and develop into protocols with natural pattern consider to be essential.

\section{References}

1. WHO (2013) Diarrhoeal disease.

2. UNICEF/WHO (2009) Diarrhoea: Why children are still dying and what can be done.

3. Black RE, Cousens S, Johnson HL, Lawn JE, Rudan I, et al. (2010) Global, regional, and national causes of child mortality in 2008: A systematic analysis. The lancet 375(9730): 1969-1987.

4. Ahs JW, Tao W, Lofgren J, Forsberg BC (2010) Diarrheal diseases in lowand middle-income countries: incidence, prevention and management. The Open Infectious Diseases Journal 4(4): 113-124.

5. WHO (2009) Diarrhoea: Why children are still dying and what can be done. Geneva: UNICEF/WHO.

6. Estimation of the Burden of Diarrhoeal diseases in India, NICED Kolkata available from on macroeconomic and health Bg P2 Estimation of the burden of diarrhoeal diseases in India.

7. Lee WS, Puthucheary SD (2002) Bacterial enteropathogens isolated in childhood diarrhoea in Kuala Lumpur-the changing trend. The Medical Journal of Malaysia 57(1): 24-30.

8. Wolf MK, Taylor DN, Boedeker EC, Hyams KC, Maneval DR, et al. (1993) Characterization of enterotoxigenic Escherichia coli isolated from US troops deployed to the Middle East. Journal of clinical microbiology 31(4): 851-856.

9. Haque R, Mondal D, Kirkpatrick BD, Akther S, Farr BM, et al. (2003) Epidemiologic and clinical characteristics of acute diarrhea with emphasis on Entamoeba histolytica infections in preschool children in an urban slum of Dhaka, Bangladesh. The American journal of tropical medicine and hygiene 69(4): 398-405.

10. DuPont HL (2000) Shigella species (bacillary dysentery), in Mandell, Douglas, and Bennett's Principles and Practice of Infectious Diseases $\left(5^{\text {th }}\right.$ edn.). pp. 2363-2369.

11. Hale TL, Keusch GT (1996) Shigella: Structure, Classification and Antigenic Types. Baron, The University of Texas Medical Branch at Galveston: Ch22.

12. Esmaeili Dooki MR, Rajabnia R, Barari Sawadkohi R, Mosaiebnia Gatabi Z, Poornasrollah M, et al. (2014) Bacterial enteropathogens and antimicrobial susceptibility in children with acute diarrhoea in Babol, Iran. Caspian J Intern Med 5(1): 30-34.

13. Pichel M, Fraga SG, Terragno R, Mulki J, Gentile A, et al. (2007) Analysis of clonal relationship among Shigella sonnei isolates circulating in Argentina. Epidemiology and infection 135(4): 681-687.

14. Ranjbar R, Dallal MMS, Pourshafie MR (2008) Epidemiology of shigellosis with special reference to hospital distribution of Shigella strains in Tehran. Archives of Clinical Infectious Diseases 3(1).

15. CDC (2009) National Centre for Zoonotic, Vector-Borne, and Enteric Diseases. Shigellosis-General Information and Frequently Asked Questions p.1-12.

16. Keusch GT, Acheson DW (1996) Shigella Infection in Enteric Infections and Immunity.
17. Trofa AF, Ueno Olsen H, Oiwa R, Yoshikawa M (1999) Dr. Kiyoshi Shiga: Discoverer of the dysentery bacillus. Clinical infectious diseases 29(5): 1303-1306.

18. Hornick RB (1977) Shigellosis. In: Hoeprich P, Paul D (Eds.). Infectious diseases. Hagerstown: Harper aid Row Publishers pp. 594.

19. Orrett FA (2008) Prevalence of Shigella serogroups and their antimicrobial resistance patterns in southern Trinidad. Journal of Health, Population and Nutrition 26(4): 456-462.

20. Yang F, Yang J, Zhang X, Chen L, Jiang Y, et al. (2005) Genome dynamics and diversity of Shigella species, the etiologic agents of bacillary dysentery. Nucleic acids research 33(19): 6445-6458.

21. Thomas LH, Gerald TK (2000) Medical Microbiology. $4^{\text {th }}$ (edn.). Baron's Medical Microbiology Shigella.

22. Ranjbar R, Dallal MMS, Pourshafie MR (2008) Epidemiology of shigellosis with special reference to hospital distribution of Shigella strains in Tehran. Archives of Clinical Infectious Diseases 3(1).

23. Kotloff KL, Winickoff JP, Ivanoff B, Clemens JD, Swerdlow DL, et al. (1999) Global burden of Shigella infections: implications for vaccine development and implementation of control strategies. Bulletin of the World Health Organization 77(8): 651-666.

24. Niyogi SK (2005) Shigellosis. Journal of Microbiology 43(2): 133-143.

25. WHO (2006) Shigella: Disease burden.

26. Michael E, Mohammad A, Mohammad Y (2008) Risk areas and neighbourhood-level risk factors for Shigella dysenteriae 1 and Shigella flexneri. Healthplace 14(1): 96-105.

27. Shane AL, Tucker NA, Crump JA, Mintz ED, Painter JA (2003) Sharing Shigella: Risk factors for a multicommunity outbreak of shigellosis. Archives of pediatrics \& adolescent medicine 157(6): 601-603.

28. Gupta A, Polyak CS, Bishop RD, Sobel J, Mintz ED (2004) Laboratoryconfirmed shigellosis in the United States, 1989-2002: Epidemiologic trends and patterns. Clinical Infectious Diseases 38(10): 1372-1377.

29. Dutta S, Dutta D, Dutta P, Matsushita S, Bhattacharya SK, et al. (2003) Shigella dysenteriae serotype 1, Kolkata, India. Emerging infectious diseases 9(11): 1471-1474.

30. Pazhani GP, Sarkar B, Ramamurthy T, Bhattacharya SK, Takeda Y, et al. (2004) Clonal multidrug-resistant Shigella dysenteriae type 1 strains associated with epidemic and sporadic dysenteries in eastern India. Antimicrobial agents and chemotherapy 48(2): 681-684.

31. Taneja N (2007) Changing epidemiology of shigellosis and emergence of ciprofloxacin-resistant Shigellae in India. Journal of clinical microbiology 45(2): 678-679.

32. Pazhani GP, Niyogi SK, Singh AK, Sen B, Taneja N, et al. (2008) Molecular characterization of multidrug-resistant Shigella species isolated from epidemic and endemic cases of shigellosis in India. Journal of medical microbiology 57(7): 856-863.

33. Von Seidlein L, Kim DR, Ali M, Lee H, Wang X, et al. (2006) A multicentre study of Shigella diarrhoea in six Asian countries: disease burden, clinical manifestations, and microbiology. PLoS Med 3(9): e353.

34. Kimura AC, Johnson K, Palumbo MS, Hopkins J, Boase JC,et al. (2004) Multistate shigellosis outbreak and commercially prepared food, United States. Emerging Infectious Diseases 10(6): 1147-1149.

35. Herwana E, Surjawidjaja JE, Salim OC, Indriani N, Bukitwetan P, et al. (2010) Shigella-associated diarrhea in children in South Jakarta, Indonesia. Southeast Asian Journal of Tropical Medicine and Public Health 41(2): 418. 
36. Chang Z, Lu S, Chen L, Jin Q, Yang J (2012) Causative species and serotypes of shigellosis in mainland China: systematic review and metaanalysis. PLoS One 7(12): 52515.

37. WHO (2001) Review of Shigella spp 8: 21-30.

38. Presterl E, Zwick RH, Reichmann S, Aichelburg A, Winkler S, et al. (2003) Frequency and virulence properties of diarrheagenic Escherichia coli in children with diarrhea in Gabon. The American journal of tropical medicine and hygiene 69(4): 406-410.

39. Levinson WE (2006) Basic bacteriology. In Review of Medical Microbiology and Immunology. New York, NY: McGraw-Hill Medical Publishing Division.

40. Ito H, Kido N, Arakawa Y, Ohta, M Sugiyama, et al. (1991). Applied and Environmental Microbiology 57: 2912-2917.

41. Schroeder GN, Hilbi H (2008) Molecular pathogenesis of Shigella spp.: controlling host cell signaling, invasion, and death by type III secretion. Clinical microbiology reviews 21(1): 134-156.

42. Phalipon A, Sansonetti PJ (1994) Shigella ways of manipulating the host intestinal innate and adaptive immune system: a tool box for survival? Immunol Cell Biol 85(2): 119-129.

43. Ashkenazi S (2004) Shigella infections in children: New insights. Semin Pediatr. Infect. Dis 15: 246-252.

44. Seidlein L, Kim DR, Ali M, Lee H, Wang X, et al. (2006) A multicentre study of Shigella diarrhoea in six Asian countries: disease burden, clinical manifestations, and microbiology. PLoS Med 3(9): 353.

45. Wassef J, Keren DF, Mailloux JL (1989) Role of M cells in initial bacterial uptake and in ulcer formation in the rabbit intestinal loop model in shigellosis. Infect. Immun 57: 858-863.

46. Perdomo OJ, Cavaillon JM, Huerre M, Ohayon H, Gounon P, et al. (1994) Acute inflammation causes epithelial invasion and mucosal destruction in experimental shigellosis. Journal of Experimental Medicine, 180(4): 1307-1319.

47. Sansonetti PJ, Phalipon A (1999) M cells as ports of entry for enteroinvasive pathogens: mechanisms of interaction, consequencesforthe disease process. Semin.Immunol 11(3): 193-203.

48. Koterski JF, Nahvi M, Venkatesan MM, Haimovich B (2005) Virulent Shigella flexneri causes damage to mitochondria and triggers necrosis in infected human monocyte-derived macrophages. Infect Immun 73: 504-513.

49. Carneiro LA, Travassos LH, Soares F, Tattoli I, Magalhaes JG, et al. (2009) Shigella induces mitochondrial dysfunction and cell death in nonmyleoid cells. Cell host \& microbe 5(2): 123-136.

50. Hathaway LJ, Griffin GE, Sansonetti PJ, Edgeworth JD (2002) Human monocytes kill Shigella flexneri but then die by apoptosis associated with suppression of proinflammatory cytokine production. Infection and immunity 70(7): 3833-3842.

51. Sansonetti PJ, Phalipon A, Arondel J, Thirumalai K, Banerjee S, et al. (2000) Caspase-1 activation of IL-1 $\beta$ and IL-18 are essential for Shigella flexneri-induced inflammation. Immunity 12(5): 581-590.

52. Ruetz T, Cornick S, Guttman JA (2011) The spectrin cytoskeleton is crucial for adherent and invasive bacterial pathogenesis. PloS one 6(5): 19940.

53. Philpott DJ, Yamaoka S, Israel A, Sansonetti PJ (2000) Invasive Shigella flexneri activates NF-kB through a lipopolysaccharide-dependent innate intracellular response and leads to IL-8 expression in epithelial cells. J Immunol 165: 903-914.
54. Islam D, Veress B, Bardhan PK, Lindberg AA, Christensson B (1997) In situ characterization of inflammatory responses in the rectal mucosae of patients with shigellosis. Infection and immunity 65(2): 739-749.

55. Sansonetti PJ (2001) Rupture, invasion and inflammatory destruction of the intestinal barrier by Shigella, making sense of prokaryote-eukaryote cross-talks. FEMS microbiology reviews 25(1): 3-14.

56. Jennison AV, Verma, NK (2004) Shigella flexneri infection: pathogenesis and vaccine development. FEMS microbiology reviews 28(1): 43-58.

57. Torres AG, Li Y, Tutt CB, Xin L, Eaves-Pyles T, Soong L (2006) Outer membrane protein A of Escherichia coli 0157: H7 stimulates dendritic cell activation. Infection and immunity 74(5): 2676-2685.

58. Mantis N, Prévost MC, Sansonetti P (1996) Analysis of epithelial cell stress response during infection by Shigella flexneri. Infection and immunity 64(7): 2474-2482.

59. Butler T (2000) Shigellosis. In: Goldman L, Bennett JC, editors. Textbook of medicine. (21 $1^{\text {st }}$ edn.), Philadelphia: WB Saunders pp. 1685-1687.

60. Khatun F, Faruque ASG, Koeck JL, Olliaro P, Millet P, et al. (2011) Changing species distribution and antimicrobial susceptibility pattern of Shigella over a 29-year period (1980-2008). Epidemiology and infection 139(3): 446-452.

61. Venkatesan MM, Ranallo RT (2006) Live-attenuated Shigella vaccines. Expert review of vaccines 5(5): 669-686.

62. Samie A, Guerrant RL, Barrett L, Bessong PO, Igumbor EO, et al. (2009) Prevalence of intestinal parasitic and bacterial pathogens in diarrhoeal and non-diarrhoeal human stools from Vhembe district, South Africa. Journal of Health, Population and Nutrition 77(6): 739-745.

63. Kumar Y, Sharma A, Sehgal R, Kumar S (2009) Distribution trends of Salmonella serovars in India (2001-2005). Transactions of the Royal Society of Tropical Medicine and Hygiene 103(4): 390-394.

64. CDC (2007) Preliminary FoodNet Data on the Incidence of Infection with Pathogens Transmitted Commonly through Food-10 States, 2006. Morbidity and Mortality Weekly Report 56(14): 336-339.

65. American Public Health Association (APHA) (2008) Shigellosis in Control of Communicable Diseases Manual pp. 556-560.

66. Haley CC, Ong KL, Hedberg K, Cieslak PR, Scallan E, et al. (2010) Risk factors for sporadic shigellosis, FoodNet 2005. Foodborne pathogens and disease 7(7): 741-747.

67. Prabhurajeshwar, Ajaykumar O, Ashajyothi C, Kelmani CR (2015) Prevalence and antibiotic susceptibility pattern of fluoroquinolone resistant Shigella species isolated from infants stool in Gulbarga district, Karnataka, India. Asian Pac J Trop Dis 5(1): 930-934.

68. Angulo FJ, Baker NL, Olsen SJ, Anderson A, Barrett TJ (2004) Antimicrobial use in agriculture: controlling the transfer of antimicrobial resistance to humans. In Seminars in pediatric infectious diseases 15(2): 78-85.

69. Angulo FJ, Nargund VN, Chiller TC (2004) Evidence of an association between use of anti-microbial agents in food animals and anti-microbial resistance among bacteria isolated from humans and the human health consequences of such resistance. Journal of Veterinary Medicine 51(8-9): 374-379.

70. Philpott DJ, Edgeworth JD, Sansonetti PJ (2000) The pathogenesis of Shigella flexneri infection: lessons from in vitro and in vivo studies. Philosophical Transactions of the Royal Society of London B Biological Sciences 355(1397): 575-586.

71. Roberts T (1989) Human illness costs of foodborne bacteria. American Journal of Agricultural Economics 71(2): 468-474. 
72. Paula CMDD, Geimba MP, Amaral PHD, Tondo EC (2010) Antimicrobial resistance and PCR-ribotyping of Shigella responsible for foodborne outbreaks occurred in southern Brazil. Brazilian Journal of Microbiology 41(4): 966-977.

73. Berhanu A, Afeworke K, Ermias D, Feleke M, Molla G (2006) The prevalence and antimicrobial responses of shigella isolates in HIV-1 infected and uninfected adult diarrhoea patients in North West Ethiopia. Ethiop J Health Dev 20(2): 99-105.

74. Njunda AL, Assob JC, Nsagha DS, Kamga HL, Awafong MP, et al. (2012) Epidemiological, clinical features and susceptibility pattern of shigellosis in the Buea Health District, Cameroon. BMC research notes 5(1): 54.

75. Srinivasa H, Baijayanti M, Raksha Y (2009) Magnitude of drug resistant Shigellosis: A report from Bangalore. Indian journal of medical microbiology 27(4): 358-360.

76. Taneja N, Mewara A, Kumar A, Verma G, Sharma M (2012) Cephalosporinresistant Shigella flexneri over 9 years (2001-2009) in India. Journal of antimicrobial chemotherapy 67(6): 1347-1353.

77. Bhattacharya D, Sugunan AP, Bhattacharjee H, Thamizhmani R, Sayi DS, et al. (2012) Antimicrobial resistance in Shigella-rapid increase \& widening of spectrum in Andaman Islands, India. Indian Journal of Medical Research 135(3): 365-370.

78. Pazhani GP, Niyogi SK, Singh AK, Sen B, Taneja N, et al. (2008) Molecular characterization of multidrug-resistant Shigella species isolated from epidemic and endemic cases of shigellosis in India. Journal of medical microbiology 57(7): 856-863.

79. Capoor MR, Nair D (2010) Quinolone and cephalosporin resistance in enteric fever. Journal of global infectious diseases 2(3): 258-262.

80. Talukder KA, Khajanchi BK, Islam MA, Dutta DK, Islam Z, et al. (2004) Genetic relatedness of ciprofloxacin-resistant Shigella dysenteriae type 1 strains isolated in south Asia. Journal of Antimicrobial Chemotherapy 54(4): 730-734.
81. Talukder KA, Khajanchi BK, Islam MA, Islam Z, Dutta DK, et al. (2006) Fluoroquinolone Resistance Linked to Both gyrA and parC Mutations in the Quinolone Resistance-Determining Region of Shigella dysenteriae Type 1. Current microbiology 52(2): 108-111.

82. Poole K (2000) Efflux-mediated resistance to fluoroquinolones in gramnegative bacteria. Antimicrobial Agents and Chemotherapy 44(9): 22332241.

83. Cabrera R, Ruiz J, Marco F, Oliveira I, Arroyo M, etal. (2004) Mechanism of resistance to several antimicrobial agents in Salmonella clinical isolates causing traveler's diarrhea. Antimicrobial agents and chemotherapy 48(10): 3934-3939.

84. Cotton MF, Wasserman E, Smit J, Whitelaw A, Zar HJ (2008) High incidence of antimicrobial resistant organisms including extended spectrum beta-lactamase producing Enterobacteriaceae and methicillinresistant Staphylococcus aureus in nasopharyngeal and blood isolates of HIV-infected children from Cape Town, South Africa. BMC infectious diseases 8(1): 40

85. Navia MM, Gascon J, Vila J (2005) Analysis of the mechanisms of resistance to several antimicrobial agents in Shigella spp. causing travellers' diarrhoea. Clinical microbiology and infection 11(12): 10441047.

86. Edwards BH (1999) Salmonella and Shigella species. Clin Lab Med 19(3): 469-487.

87. Venkatesan MM, Ranallo RT (2006) Live-attenuated Shigella vaccines. Expert review of vaccines 5(5): 669-686

88. Yang HH, Wu CG, Xie GZ, Gu QW, Wang BR, et al. (2001) Efficacy trial of Vi polysaccharide vaccine against typhoid fever in south-western China. Bulletin of the World Health Organization 79(7): 625-631.

89. Lin FYC, Ho VA, Khiem HB, Trach DD, Bay PV, et al. (2001) The efficacy of a Salmonella typhi Vi conjugates vaccine in two-to-five-year-old children. New England Journal of Medicine 344(17): 1263-1269.

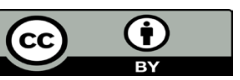

This work is licensed under Creative Commons Attribution 4.0 License

Submission Link: Submit Article

DOI: $10.32474 / C D V S .2018 .01 .000121$

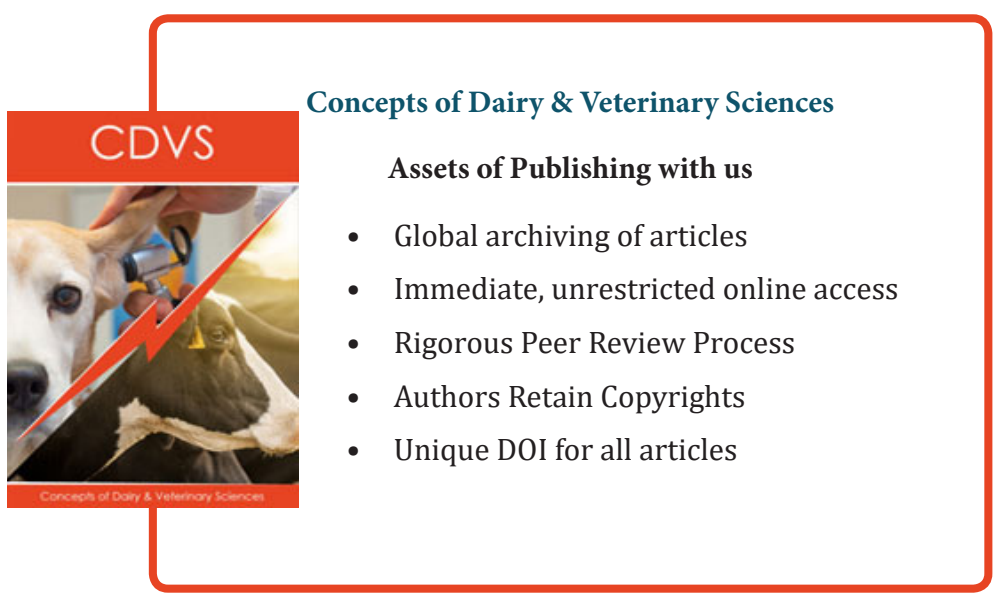

